S. Wamberg 1

J. Elnif 2

A.-H. Tauson ${ }^{2}$

\section{Rates of urinary water electrolyte and nitrogen excretion in fed and fasted female mink (Mustela vison)}

\section{Renale Elektrolyt- und Stickstoffausscheidung}

Accurate determination of daily urinary excretion rates of xenobiotics, dietary constituents and end products of metabolism in experimental animals is a prerequisite for measurements of renal function and for the evaluation of nutritional requirements. In balance studies with small carnivores whole-body balances are usually over-estimated because of the excretion of a highly concentrated urine and because of their habit of squirting.

In the present study we have used implanted osmotic pumps containing labeled p-aminohippuric acid (PAH) and inulin (IN) for accurate determination of quantitative urine collection in conscious mink (1). Ten female mink of the pastel type, weighing $1100 \pm 34 \mathrm{~g}$, had a $2-\mathrm{ml}$ Alzet ${ }^{\mathrm{R}}$ osmotic pump, containing known amounts of $\left[{ }^{3} \mathrm{H}\right]-$ PAH $(1.85 \mathrm{MBq} / \mathrm{ml})$ and $\left[{ }^{14} \mathrm{C}\right]-\mathrm{IN}(0.925 \mathrm{MBq} / \mathrm{ml})$, im planted intraperitoneally during ketamine anaesthesia. The in vitro pumping rate $(9.96 \pm 0.12 \mu \mathrm{l} / \mathrm{h} ; \mathrm{n}=10)$ of the pumps measured at $39.0^{\circ} \mathrm{C}$ verified the nominal value $(10.00+0.46 \mu \mathrm{l} / \mathrm{h})$ supplied by the manufacturer. On re-

S. Wamberg' ${ }^{1}$ J. Elnif ${ }^{2}$ \& A.-H. Tauson ${ }^{2}$

${ }^{1}$ Dept. of Physiology, Institute of Medical

Biology

Odense University

DK-5000 Odense C.

${ }^{2}$ Dept. of Animal Science and Animal

Health, The Royal Veterinary

and Agricultural University

DK-1870 Frederiksberg C.

Denmark covery the animals were maintained in metabolic cages on a conventional mink diet and studied for a 5-day feeding period followed by a 2-day fast. Drinking water was available ad lib. throughout the study. In the fed animals the recovery rates of $\left[{ }^{3} \mathrm{H}\right]-\mathrm{PAH}$ and $\left[{ }^{14} \mathrm{C}\right]-\mathrm{IN}$ were almost identical $(77.0 \pm 8.3 \%$ vs. $77.2+7.4 \%)$ and a little lower in fasted animals $(72.2 \pm 17.2 \%$ vs. $71.1+13.0 \%$ ). The glomerular filtration rate (GFR) was calculated as the renal clearance of $\left[{ }^{14} \mathrm{C}\right]$-inulin.

The results (mean $\pm \mathrm{sd}$ ) obtained in fed and fasted mink, corrected to $100 \%$ recovery, are presented in the Table below. During feeding urinary volume was not influenced by the experiment, whereas short-term fasting caused a dramatic reduction in GFR and in daily urinary water and solute excretion, due to withdrawal of the normal dietary protein and water load.

Table 1. Urinary excretion rate in fed and fasted mink

\begin{tabular}{lcc}
\hline Urinary excretion rate & Fed mink & Fasted mink \\
\hline Urine volume, ml/d & $87 \pm 32^{\mathrm{a}}$ & $22 \pm 7$ \\
Sodium, mmol/d & $2.3 \pm 0.9$ & $0.1 \pm 0.1$ \\
Potassium, mmol/d & $8.4 \pm 2.7$ & $1.3 \pm 0.2$ \\
Urea, mmol/d & $119 \pm 37$ & $12.0 \pm 2.9$ \\
Creatinine, mmol/d & $0.53 \pm 0.09$ & $0.18 \pm 0.03$ \\
Total nitrogen, g/d & $3.64 \pm 1.18$ & $0.65 \pm 0.14$ \\
GFR, ml/min & $7.66 \pm 2.82^{\mathrm{b}}$ & $3.93 \pm 0.52^{\mathrm{b}}$ \\
\hline
\end{tabular}

aValues are mean $\pm s d(n=10)$, bexcept for GFR $(n=5)$

\section{References}

1. Wamberg S, Elnif J, Tauson, A-H (1996) Assessment of the accuracy of quantitative urine collection in mink (Mustela vison) using osmotic pumps for continuous release of p-amino-hippuric acid and inulin. Laboratory Animals 30:267-273. 